\title{
AKWẼ XERENTE DEIXA DE SER CRIANÇA MAIS OU MENOS AOS 40 ANOS
}

\author{
Manoel Sirnãrê Xerente \\ Professor Alfabetizador
}

Silvino Sirnãwẽ Xerente

Formador conteudista

\section{ROWASKUKTURÊ}

Tô aimõ wat wasku mnõ nmẽ, aikterê dadki wamre, za aimõ sepakwai mẽ, tanẽkõwa separkwa aimõ tkrê wapar, mãrĩ ĩseparkwa tê kmãkwamãr wa, za aikterê dure kmãnã, sipi wa, krmõr wa, sai wa, za aimõ wapa. Tô tanẽ dure waptkã pari, za tokto aimõ ro tkrê sãmr nnãkrat, za tkrê kupi nnãkrat, kãtô dure mãrĩ tê waihku nẽhã za kmãnã, kãtô separkwa za tkrê waihâk, kãtô ptokwa tkrê waihâk, kuptu mnõ pari, kãtô kbure ro tê waihku mnõ pari, zatô siwaprosi krmõ.

PALAVRAS-CHAVE: aikde, dapkezanize, dazeparkwa.

\section{RESUMO}

Como a gente tinha falado sobre a vida das crianças akwẽ que são cuidadas desde que começam a participar de tudo que a mãe faz isso é na gravidez delas. A criança começa participar junto com a mãe, tudo que ela faz a criança participa. A vida das crianças é muito importante, começando sentir, participar tudo que a mãe faz a mãe trabalhando, na roça, fazendo artesanatos, na caçada, pescando, na tinguizada, e na festa cultural. Depois que a criança nasce, começa ver, entender e começa praticar, e depois ajudando a mãe, o pai e outras pessoas que têm contato direto com ele ou ela. Depois que eles começam fazerem as coisas sozinhas, aí eles sentem de verdade que já estão prontos para seguir a vida, tudo que foi repassado quando estavam na barriga da mãe, e depois que eles conhecem a realidade, tudo que eles precisam aprender é ensinado, e repassado.

PALAVRAS-CHAVE: criança, vida, mãe. 
Falando sobre a vida Akwẽ, desde criança até mais ou menos quarenta anos de idade. Como a gente tinha já falado, o ciclo da vida das crianças Akwẽ começa na barriga da sua mãe. Quando a mãe fica grávida, já começa a vida das crianças, participando de todas as atividades que a mãe faz porque a criança fica ali dentro da barriga da mãe, participando e presenciando o que a mãe vê e faz, e também na alimentação que ela come. É muito importante a alimentação da mãe quando ela está na gravidez. Depois que a criança nasce os pais cuidam com maior carinho dos filhos, que é chamado de aktepre (criança recém nascido).

Depois vai só passando de fases até chegar à idade de quarenta anos, ou mais, quando começa a ser chamada de turê, krêpdu, wapte, até chegar ĩptokrda e wawẽ snĩ ambâ. Como também as mulheres: tarê, bakrda, snã ainã, ĩssuibka, ĩptokrda, e wawẽ sĩ pikõ. Todos esses nomes são colocados quando passamos de fase até chegar a certa idade, por exemplo, o nome turê é masculino, que é o menino chamado de 9 a 10 anos de idade, e tarê é menina, que é a mesma coisa de masculino, até chegar à fase krêpdu, que é menino, e bakrda, que é menina.

Quando é chamada de krêpdu já na idade de 11 a 17 anos de idade, mesma coisa para as meninas. Quando é chamada de wapte, quando tem a idade de 18 a 30 anos, como para masculinos e femininos, quando é chamado de idumkrda ou iptokrda, quando tem a idade de 31 a 61 anos de idade, como para masculinos e femininos. Aí vem a palavra wawẽ, que é acima de 62 anos de idade, que é considerado a biblioteca para os novos.

Os wawẽ são a principal autoridade de cada aldeia. Isso vem desde a época que tinha Warã, casas de solteiros que hoje não existem mais, mas temos as escolas que ensinam o que era ensinado no Warã. Nessa fase cada um faz o seu dever como masculinos e femininos. Antigamente eles faziam muitas atividades físicas ajudando os pais, na roça, a pescar e caçar, pegar frutas, fazer caminhada, participar da festa cultural, e outras atividades, que são feitas na sua aldeia. Os homens participam mais que as mulheres, como pescaria, caça, trabalho, festa cultural. As mulheres fazem atividades mais dentro de casa, como cozinhar, lavar roupas, cuidar das crianças, fazer artesanatos, e participar da festa cultural, cantorias. Anciãs também 
são contadoras de história que conhecem muitas das histórias que elas repassam para os netos e outras pessoas que procuram elas. Essa é a história de ciclo da vida das crianças. 